\title{
Long-term changes in macrofaunal communities off Norderney (East Frisia, Germany) in relation to climate variability
}

\author{
I. Kröncke ${ }^{1, *}$, J. W. Dippner ${ }^{2}$, H. Heyen ${ }^{3}$, B. Zeiss ${ }^{1}$ \\ ${ }^{1}$ Forschungsinstitut Senckenberg, Abteilung für Meeresforschung, Schleusenstr. 39a, D-26382 Wilhelmshaven, Germany \\ ${ }_{2}^{2}$ Max-Planck-Institut für Meteorologie, Bundesstr. 55, D-20146 Hamburg, Germany \\ ${ }^{3}$ GKSS, Institut für Gewässerphysik, Max-Planck-Strasse, D-21502 Geesthacht, Germany
}

\begin{abstract}
Macrofaunal samples were collected seasonally from 1978 to 1995 in the subtidal zone off Norderney, one of the East Frisian barrier islands. Samples were taken with a $0.2 \mathrm{~m}^{2}$ van Veen grab at 5 sites with water depths of 10 to $20 \mathrm{~m}$. Interannual variability in biomass, abundance and species number of the biota were related to interannual climate variability using multivariate regression models. Changes in the biota were described in relation to human impact and seasonal and long-term meteorological variability. Our analyses suggest that macrofaunal communities are severely affected by cold winters, whereas storms and hot summers have no impact on the communities. It appears that mild meteorological conditions, probably acting in conjunction with eutrophication, have resulted in an increase in total biomass since 1989. A multivariate model found the following strong relationship: abundance, species number and (less clear) biomass in the second quarter are correlated with the North Atlantic Oscillation (NAO). The mediator between the NAO and benthos is probably the seasurface temperature (SST) in late winter and early spring. On the basis of our results, we suggest that most of the interannual variability in macrozoobenthos can be explained by climate variability.
\end{abstract}

KEY WORDS: Macrofauna - Climate - Long-term variability - German Bight - North Atlantic Oscillation Multivariate statistics

\section{INTRODUCTION}

Interannual and interdecadal variabilities are often observed in biological time series and clearly influence trophic relationships in the marine ecosystem. Variability is frequently characterized by a periodicity of 3 to 4 yr (Steele 1974, Colebrook \& Taylor 1984). In the North Sea, interannual and interdecadal variabilities have been observed in oceanographic and ecological processes (Cushing \& Dickson 1976). During the last century 2 major events were observed in the North Sea, the so-called 'Russell cycle' (Russell 1973) and the Great Salinity Anomaly (GSA) (Dickson et al. 1988).

The Russell cycle affected the North Sea and English Channel. From 1925, the dominant herring and macrozooplankton community were replaced by pilchards

\footnotetext{
-E-mail:kroencke@sam-terramare.fh-wilhelmshaven.de
}

and smaller zooplankton. The chaetognath Sagitta elegans, a recognized indicator species of Atlantic Water, was replaced by $S$. setosa, the corresponding form in the southern North Sea (Russell 1973). At the same time haddock disappeared from the German Bight and haddock larvae were recorded off Plymouth, UK, where they had not been observed in the preceding $50 \mathrm{yr}$ (Russell 1973). These and other profound ecosystem changes were reversed between 1965 and 1979, when more northwesterly winds prevailed once again and the community began to revert to the former composition (Cushing 1978).

The strongest interdecadal change in the North Sea was the appearance of the GSA between 1977 and 1978 (Dickson et al. 1988). The GSA, a large cold water body with low salinity, entered the northern North Sea and had many ecological consequences (Aebischer et al. 1990, Lindeboom et al. 1995). In the northern North Sea, 
the abundance of phytoplankton and herring decreased, with a distinct minimum in the late 1970s (Colebrook 1986, Daan et al. 1990). Phytoplankton and zooplankton data collected in the North Sea with a continuous plankton recorder (CPR) (Colebrook 1986) showed that there was marked decrease in zooplankton abundance in 1978, followed by an increase in 1982 .

When the GSA appeared in the northern North Sea there were congruent changes in the southern North Sea and the Wadden Sea. Flagellate abundance in the German Bight increased during 1979 at Helgoland Roads (Hickel et al. 1993). In the Wadden Sea the biomass of macrozoobenthos increased suddenly between 1979 and 1981 (Beukema 1991), whereas the phytoplankton data indicated a doubling of chlorophyll a between 1976 and 1978 (Cadée \& Hegemann 1991). In 1977 only 9 eider chicks fledged in the western Wadden Sea, whereas in 1978 more than 1000 successful fledglings were reported (Swennen 1991).

In contrast, a positive salinity anomaly was observed in the southern North Sea between 1989 and 1991 (Becker et al. 1992, Becker \& Dooley 1995). This positive anomaly was connected with a strong inflow of Atlantic water masses through the English Channel. Similar events of positive salinity anomalies caused by strong inflow of Atlantic water masses were observed by German light vessels in November 1934, from February to April 1973 and in November 1977 in the German Bight during the GSA event in the northern North Sea (Deutsches Hydrographisches Institut 1984). The strong inflow of Atlantic water masses into the southern North Sea during 1989 coincided with recolonization by the flagellate Gymnodinium catenatum (Nehring 1994) and the appearance of Lepidodinium viride in the German Bight.

The appearance of the GSA between 1977 and 1978 in the northern North Sea and the opposite effect of a positive salinity anomaly between 1989 and 1991 in the southerm North Sea were associated with the farfield forcing of the Atlantic Ocean and the connected variability in the inflow regimes. However, hydrographic changes in the North Sea are also controlled by the direct effect of atmospheric forcing (e.g. radiation or air-sea exchange processes). Becker \& Pauly (1996) and Dippner (1998a) have shown that in nearly all areas of the North Sea the sea-surface temperature (SST) anomalies are correlated with the North Atlantic Oscillation (NAO) index. Heyen \& Dippner (1996, 1998) demonstrated that the interannual and interdecadal variability in surface salinity at German light vessels is strongly correlated to the river runoff with a time lag between 2 and 4 mo. In ecological terms, it is important to identify the proportion of variance in biological time series which may be attributed to climate variability.
Long-term changes in observations of North Sea macrofauna have been described by Rees \& Eleftheriou (1989) and Kröncke (1995). Changes were discussed in relation to environmental effects such as temperature (Ziegelmeier 1970, Beukema 1979, 1990, 1992, Dörjes et al. 1986), storms (Rachor \& Gerlach 1978) and currents or anthropogenic impacts like eutrophication (Beukema \& Cadêe 1986, Rosenberg et al. 1987, Rachor 1990), pollution (Borchardt et al. 1988, Karbe et al. 1988, Kersten \& Kröncke 1991) and fisheries (de Groot \& Lindeboom 1994). In addition, several studies have emphasized that effects may be synergistic (Rees \& Eleftheriou 1989, Kröncke 1992). The macrofauna of the coastal waters have been studied at a site to the north of Norderney since 1978. J. Dörjes sampled monthly from 1978 to 1991, but since 1992 sampling has been restricted to late winter and late summer. In the present naner we describe the long-term variability in the macrofauna at this site and relate these data to the interannual variability of several climate parameters.

We adopt 2 approaches to the analyses, an empirical and a statistical approach. The empirical analysis is used to identify extremes and trends in the biological and climatological time series. The multivariate 'statistical downscaling' approach is normally used in climate impact research (von Storch et al. 1993, Heyen et al. 1996). One powerful feature of this method is that it can be used to detect relationships between a vector of predictors (e.g. climate parameters) and a vector of predictands (e.g. biological parameters). This technique has rarely been applied to biological time series, but when used it has permitted the derivation of biological parameters from large-scale climate variables in both terrestrial and. marine ecosystems. Maak \& von Storch (1997) demonstrated that the date at which the flowering of snowdrops began in Germany and the United Kingdom could be predicted from the large-scale development of air temperature fields. Dippner (1998b) showed that variability in the recruitment of different fishes in the North Sea was strongly correlated to the NAO index and the SST anomalies in the North Sea. In the Pacific Ocean, Mantua et al. (1997) showed that the anomalies in the Alaskan salmon catch corresponded to the prevailing polarity of the Pacific inter-decadal Oscillation (PDO). A similar relationship between the southern oscillation and fish stocks was shown by Binet (1997).

In the present paper the Iong-term variability of benthic macrofauna in the southern North Sea is investigated with respect to large-scale climate variability. The central question is how much of the observed variability in macrozoobenthos can be attributed to the interannual variability of atmospheric pressure fields and the variability of sea-surface temperature in the southern North Sea? 


\section{MATERIAL AND METHODS}

Benthos data. The area of investigation was situated north of the island of Norderney in the Wadden Sea, southern North Sea. Five stations were located in water depths between 12 and $20 \mathrm{~m}$. Samples were taken with a $0.2 \mathrm{~m}^{2}$ van Veen grab and washed over a sieve of $0.63 \mathrm{~mm}$ mesh size. Samples were taken monthly from 1978 to 1991, but since 1992 sampling has been restricted to late winter and late summer. Prior to statistical analysis all samples were revised taxonomically. Species number, abundance and biomass (ash-free dry weight) were calculated as means per $0.2 \mathrm{~m}^{2}$ or of $5 \mathrm{sta}$ tions and were given as values per yearly quarter Mean water temperatures varied from $18.5^{\circ} \mathrm{C}$ in July/ August to $2.0^{\circ} \mathrm{C}$ in January/February until 1986 (Dörjes et al. 1986). Highest air temperatures occurred in the hot summers 1982, 1983 and 1984. The winters $1978 / 1979,1981 / 1982,1984 / 1985$ and $1985 / 1986$ were colder than the long-term monthly average (Zeiss \& Kröncke 1997).

Climatic variables. NAO index: The dominant signal of interannual variability in the atmospheric circulation is the NAO (Walker \& Bliss 1932, Barnston \& Livezey 1987, Lamb \& Peppler 1987, Kushnir \& Wallace 1989, Hurrell 1995). An analysis with empirical or thogonal functions (EOFs) (also known as 'principal components') of the mean sea level pressure fields from December to March over the region from $20^{\circ} \mathrm{N}$ to $80^{\circ} \mathrm{N}$ and $90^{\circ} \mathrm{W}$ to $40^{\circ} \mathrm{E}$ revealed that the $\mathrm{NAO}$ is the dominant source of the atmospheric variability and explains more than $36 \%$ of variance in climate. Barnston \& Livezey (1987) showed that the NAO was evident in monthly mean data throughout the year but that it was most pronounced during wintertime. The NAO index variability since 1864 is shown in Fig. 1 (Hurrell 1995). Hurrell (1995) defines the NAO index as the difference between the normalized sea level pressure anomalies during wintertime at Lisbon, Portugal, and Stykkisholmur, Iceland. The sea level pressure anomalies at

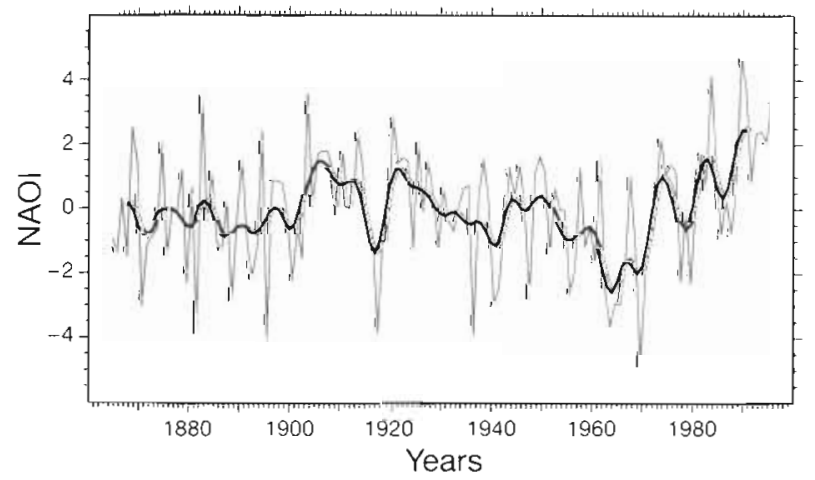

Fig. 1. North Atlantic Oscillation index (NAOI) for winter after Hurrell (1995). Thick line: low-pass filtered time series each station were normalized by division of each seasonal pressure by the long-term mean (1864 to 1994) standard deviation. An equivalent definition, the spatial difference in sea level pressure anomalies between Ponta Delgada, The Azores, and Akureyri, Iceland, was used by Lamb \& Peppler (1987). A high index is associated with strong westerly winds and a low index with low westerly winds. During high NAO winters the westerly winds over Europe are over $8 \mathrm{~m}$ $\mathrm{s}^{-1}$ stronger than during low NAO winters and consequently, during high NAO winters, the moderating influence of the ocean results in unusually warmer winter temperatures in Europe (Hurrell 1995). The NAO index data used in this paper were kindly provided by James Hurrell from the National Center of Atmospheric Research (NCAR), Boulder, CO, USA.

Weekly SST data: Since autumn 1968 the German Hydrographic Institute (now Federal Maritime and Hydrographic Agency, BSH) has analyzed and distributed weekly SST charts of the North Sea. These SST maps are based on near-surface temperature observations from ship-of-opportunity programs, commercial vessels, light vessels, fixed stations and buoys, coastal stations, research vessels and monitoring programs (Mittelstaedt 1969, Becker et al. 1986, Becker \& Pauly 1996). Time serics of SST anomalies were constructed by subtracting the long-term seasonal mean temperature from the SST The anomalies of these long-term data sets are analyzed with EOFs. Fig. 2a shows the first SST EOF for the months January to March, which represents $87 \%$ of the SST variance. The time series of the first principal component of the SST anomalies in the North Sea (Fig. 2b) is highly correlated with the NAO index (Dippner 1998a), with a correlation coefficient of $\mathrm{r}=$ 0.71 and a confidence level of $97.9 \%$. One-month, 3-mo and 6-mo running means of SST were used as input for the multivariate regression model.

The stations for macrozoobenthos sampling are located in the homothermal part of the Continental Coastal Water, a water mass of low salinity, high nutrient concentration and high turbidity. This water mass is homothermal throughout the year due to the pronounced influence of the coast and the intensive mixing in the shallow parts of the North Sea (Laevastu 1962). As a result, the SST is identical to the bottom temperatures which influence the macrofauna.

other climatic data: In order to examine the wider effects of climate we tested relationships between benthic communities and the following:

- Monthly means of sea-level air pressure (SLP) fields (includes the $\mathrm{NAO}$ ) from $20^{\circ} \mathrm{W}$ to $10^{\circ} \mathrm{E}$ and $45^{\circ} \mathrm{N}$ to $65^{\circ} \mathrm{N}$ (NCAR) with a resolution of $5^{\circ} \times 5^{\circ}$ (Trenberth \& Paolino 1980). This data set also contains indirect information about advection of temperature and precipitation, storminess and wind direction 

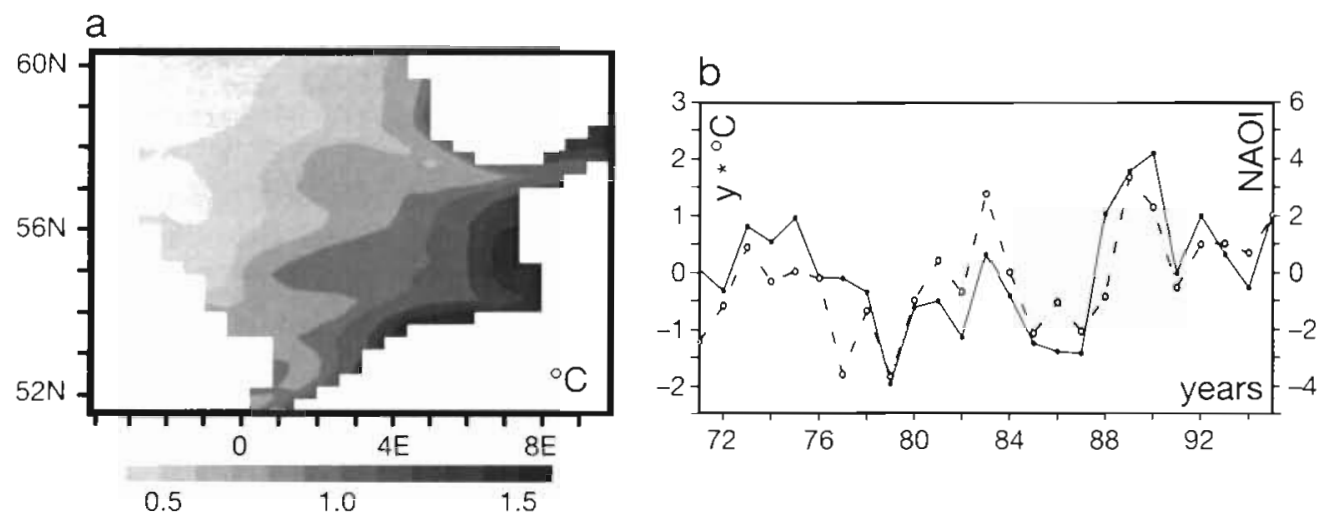

Fig. 2. (a) Pattern of the first EOF (empirical orthogonal function) of the January to March SST (sea-surface temperature). This EOF explains $87 \%$ of the SST variance in this season. The pattern can be interpreted as a North Sea that is either anomalously warm (in the years where the time coefficient is positive) or anomalously cold (if the time coefficient is negative), with the highest anomalies occurring in the southeast. (b) Time coefficient of the first EOF $(\bullet$ ) compared to the NAO index (o- - ) . The correlation is $r=0.71$. Obviously, the SST in the North Sea is strongly coupled to the NAO

- Monthly means of storm activity (CYC) (same field size and resolution) computed from the the daily NCAR sea level pressure data. From the SLP data set, the variance on the 2.5 io 6 d frequency band was calculated as a proxy for storm activity (Blackmon 1976).

- Monthly means of air temperature (T) (same field size and resolution) (Jones 1994).

- Monthly means of the Gulf Stream index (GSI), which is a measure of the northward extension of the Gulf Stream (Taylor 1995).

- Discharge from the River Elbe, Germany (with friendly help from the Arbeitsgemeinschaft Elbe, ARGE).

- Monthly means of high and low tide at Helgoland (kindly provided by the Biologische Anstalt Helgoland).

The statistical model. Definition of the problem: When we started to investigate the existence of a relationship between the interannual variability in climate and benthos, we were uncertain as to which climate parameters should be examined. As a result, we aimed to include several potential predictor variables in the investigation. This approach posed 2 problems. Firstly, if the relationship is not known, how can it be identified and, secondly, how can the overdetermination of a relationship based on multiple predictors be avoided.

We adopted the 'statistical downscaling' model of von Storch et al. (1993). The features of this model overcome the problems described above since: (1) sets of information from fields of predictors and predictands can be related to each other; (2) the dimensionality of the model can be kept low; (3) the highest correlations are detected automatically.

Description of the statistical model: The aim of the statistical analyses was to correlate all 'potential' predictor variables with the benthos observations via the

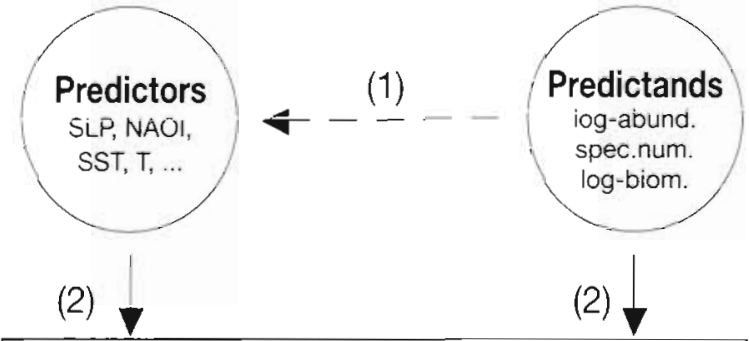

For each combination of predictor and predictand

(3)

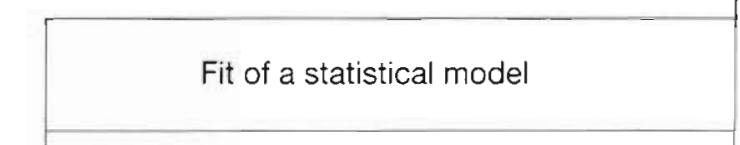

Computation of skill with independent data

For each combination of predictor and predictand

(4)

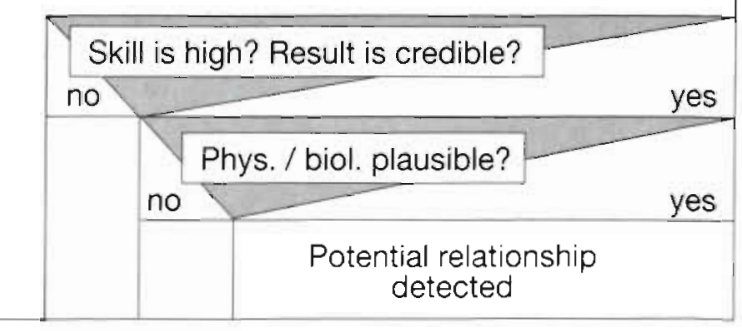

Fig. 3. Outline of the applied method. Depending on the benthos predictands (top right), possible predictor variables are collected (1). One specific combination of predictor and predictand is selected (2). Between predictor and predictand, a statistical model is fitted, validated with independent data, and a skill factor is computed (3). Procedure 3 is repeated for all combinations of predictor and predictand. Thereafter, the combinations with the highest skills are selected and their credibility is checked for statistical significance and physical or biological plausibility (4). A combination that passes all these tests probably indicates that a relationship exists 
multivariate model and to identify high correlations. This approach is outlined in Fig. 3. The predictands are the anomalies (in the seasonal cycle) of log abundance, species number and log biomass, separated into seasons. Seasonal separation is used because the relationship between climate and benthos may depend on the season. The potential predictors contain the anomalies of SST, SLP, CYC, T, GSI, River Elbe runoff and Helgoland tidal data. Since the sought relationship might occur on specific timescales, 1-, 3-, and 6-mo means of each predictor were calculated. The predictors were also separated into seasons for the reasons described above.

The calculation starts with the selection of 1 specific predictor and 1 specific predictand, e.g. 'SLP, 3-mo average, centered around January' and 'log abundance, first quarter of the year' A statistical model is fitted between them and validated. The result of the validation is a skill factor. This procedure is repeated for all possible combinations of potential predictors and predictands. A possible time lag of 1 yr between the signals in climate and benthos was taken into account.

In a second step the combinations with the highest skills are selected and tested for their statistical significance. Finally, the physicai or biological plausibility of the remaining combinations has to be evaluated. A combination that passes all these tests probably indicates that a relationship exists.

Fit, regression and validation: For each combination of potential predictor and predictand, the model is built in the following way. Firstly, EOFs of the predictor and predictand are calculated. Thus, the major part of the variance from a multidimensional vector (for example a SLP field with many stations) is concentrated into a few new dimensions, the leading eigenmodes. Secondly, a Canonical Correlation Analysis (CCA) is performed between the leading eigenmodes of the climate predictor and the benthos time series. The CCA identifies patterns $\vec{C}$ and $\vec{B}$ and time series $\vec{C}$ and $\vec{b} . \vec{C} \times c(t)$ represents a significant part of the variance of the climate predictors, $\vec{B} \times b(t)$ is the investigated benthos time series with $\vec{B}$ being a constant vector and $\vec{b}$ a normalized time series (in the present study, $\vec{B}$ is a scalar since the predictand is a single time series; generally, one can take a multivariate predictand instead, e.g. the spatial distribution of abundances). $\vec{C}$ and $\vec{b}$ are optimally correlated to each other. Hence, thirdly, the benthos time series $\overrightarrow{\mathbf{B}}=\vec{B} \times b(t)$ can be regressed from predictor data as $\overrightarrow{\mathbf{B}}_{\mathrm{reg}}=\vec{B} \times c(t)$.

Since CCA correlations are optimized with respect to the used sample, it is necessary to validate the correlation with independent data. In contrast to von Storch et al. (1993), who splitted the records into a fitting and a validation period, we use a cross-validation technique
(Michaelsen 1987). If $n$ time steps of data are available, $n$ models are fitted using $n-1$ different time steps each. For each model, the $n$th step of the predictand is regressed from the predictor. Finally, the $n$ estimations are compared with the observations of the predictand. Detailed informations about EOFs and CCA are given in von Storch (1995).

Selection of the results: From all tested combinations, the results with the relatively highest skills were selected. 'Relatively highest' means that we looked for combinations of predictor and predictand that possessed a maximum of skill within a narrow range of time lags and clearly lower skills for any other time lags. As skill factors, correlation coefficient r (between the benthos observations and the cross-validated estimations) and Brier-based score $\beta$ were used. $\beta$ is defined as: $\beta=1-\sigma_{\mathrm{e}}^{2} / \sigma_{0}^{2}$, where $\sigma_{\mathrm{e}}^{2}$ and $\sigma_{0}^{2}$ are the variances of the error (i.e. observation minus model) and observations. $\beta=1$ means that model and observation are identical, $\beta=0$ that the error of the model has the same size as the variance of the observations (Livezey 1995)

The significance level of the selected results was calculated by generating 10000 series of random numbers with the same statistical properties (mean, standard deviation, autocorrelation) as the EOF coefficients of the predictor (the climatic predictor was chosen since its statistical properties are better known and more Gaussian-distributed than that of the benthos). These series were related by CCA to the benthos data in the same way as the real EOF coefficients were.

Since the discarding of combinations with 'relatively low skill' or 'low significance' is necessarily subjective, the presented results cannot be described as complete but provide a sample of 'most probable relationships'.

\section{RESULTS}

\section{Benthic data}

In total, 196 taxa were found in 351 samples 181 Crustacea, 59 Polychaeta, 32 Mollusca, 9 Echinodermata and 15 others). In the first quarter, mean species numbers varied between 9 (1979) and 28 (1992) per $0.2 \mathrm{~m}^{2}$. Between 1980 and 1989 species numbers were below 24 per $0.2 \mathrm{~m}^{2}$, but after 1991 they were above 24 per $0.2 \mathrm{~m}^{2}$ (Fig. 4a). In the second quarter the lowest species number was found in 1979 with 11 species per $0.2 \mathrm{~m}^{2}$. Highest species numbers occurred in 1990 (42) and there were more than 30 species per $0.2 \mathrm{~m}^{2}$ in 1992 and 1993 (Fig. 4b). Species numbers were usually higher in the third quarter and only fell below 30 per $0.2 \mathrm{~m}^{2}$ in 1979 and 1989 (Fig. 4c). Species numbers were lowest during the fourth quarter and only 18 per $0.2 \mathrm{~m}^{2}$ were found in 

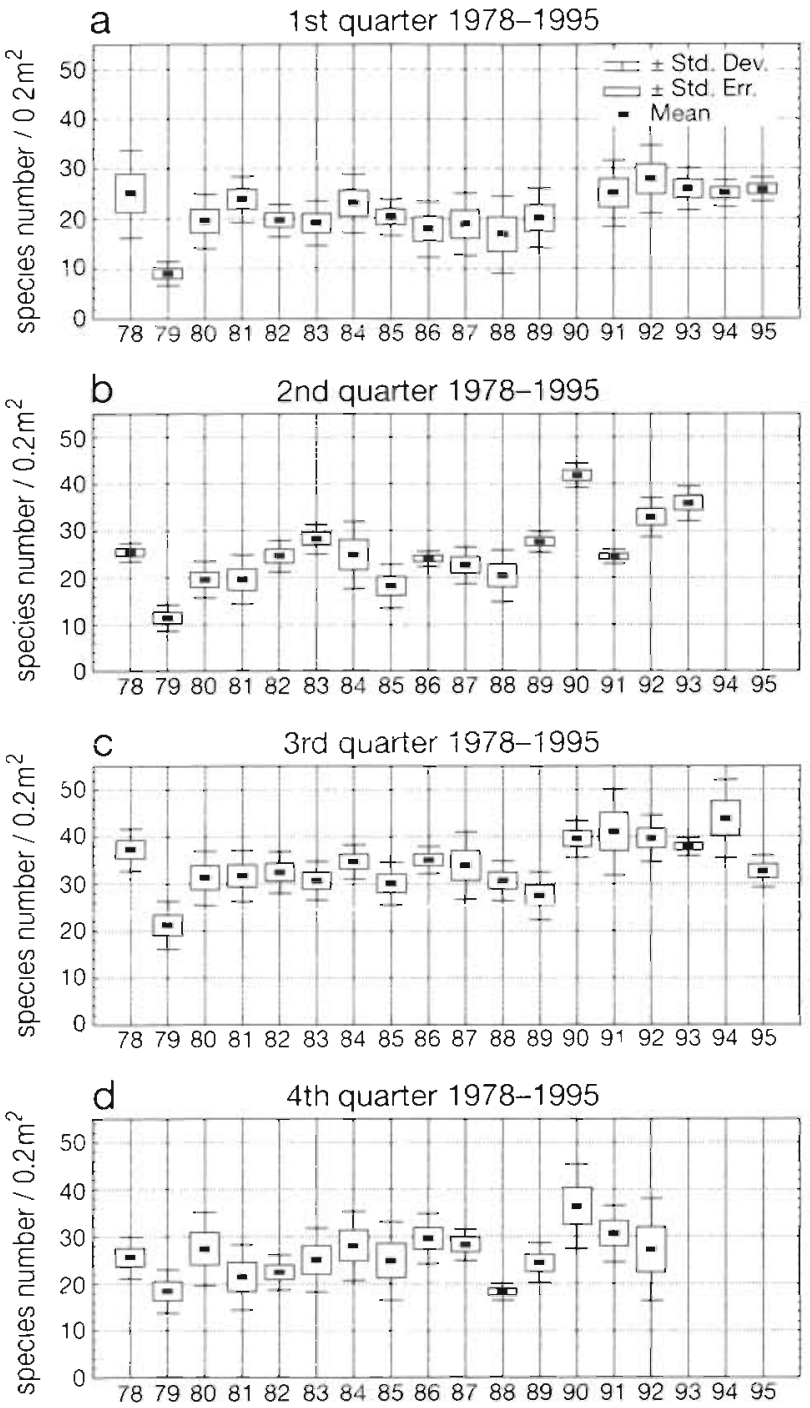

Fig. 4 Mean species numbers per $02 \mathrm{~m}^{2}$ for the furst to fourth quarter ( $a$ to d) between 1978 and 1995

1979 and 1988. More than 30 species per $0.2 \mathrm{~m}^{2}$ were recorded in 1990 and 1991 (Fig. 4C)

Mean abundance in the first quarter varied between 440 (1979) and 3363 (1981) ind. $\mathrm{m}^{-2}$ (F1g 5a). In the second quarter the lowest values were recorded in 1980 and 1988 with 1252 and 961 ind. $\mathrm{m}^{-2}$ respectively. The highest abundance was 5785 ind. $\mathrm{m}^{-2}$ in 1990 (Fig. 5b). During the third quarter the maximum abundance was recorded in 1982 with 12730 and the minlmum in 1989 with 1479 ind $\mathrm{m}^{-2}$ (Fig 5c). Durng the fourth quarter the greatest abundance occurred in 1980 and 1982 with 6115 and 5865 ind. $\mathrm{m}^{-2}$ respectuvely. During other years the abundance ranged between 774 and 2956 ind. $\mathrm{m}^{2}$ (Fig 5d).

Mean total biomass during the first quarter vaned between 263 and $1123 \mathrm{mg} \mathrm{m}^{-2}$ in the years 1978 to
1988. In 1989 the biomass increased to $1715 \mathrm{mg} \mathrm{m}^{-2}$ ( $F 1$ g 6a). The lowest biomass was recorded in the second quarter in 1979 with $78 \mathrm{mg} \mathrm{m}^{-2}$ (Flg 6b) B1omass increased after 1988 and the highest value was reached $1 n 1990$ with $3.96 \mathrm{~g} \mathrm{~m}^{-2}$ In the third and fourth quarters biomass tended to remain low up to 1987 , with maxima of 1 and $0.7 \mathrm{~g} \mathrm{~m}^{-2}$, but increased after 1987 to maxima of 2.9 and $2.8 \mathrm{~g} \mathrm{~m}^{-2}$ respectively (Fig 6c, d).

\section{Benthos in relation to climate}

Table 1 gives an overview over the combinations with the highest skills. Three things are worth noting Firstly, all combinations refer to benthos data in the

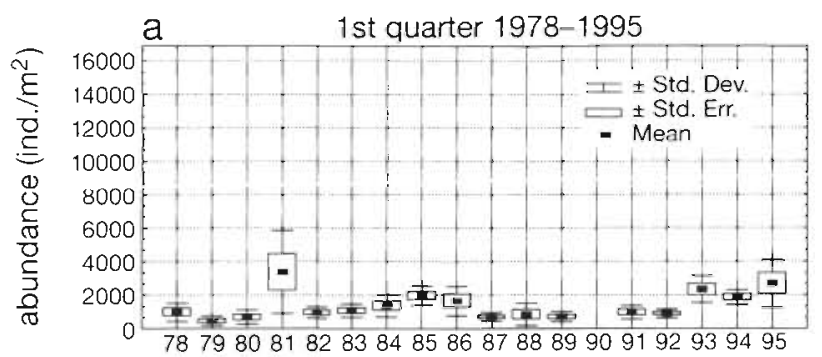

b

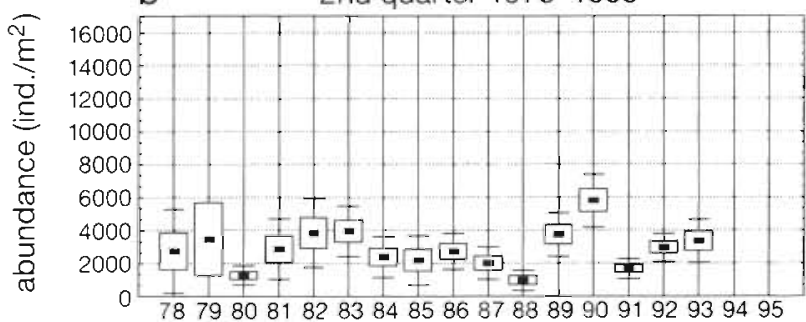

C 3rd quarter 1978-1995
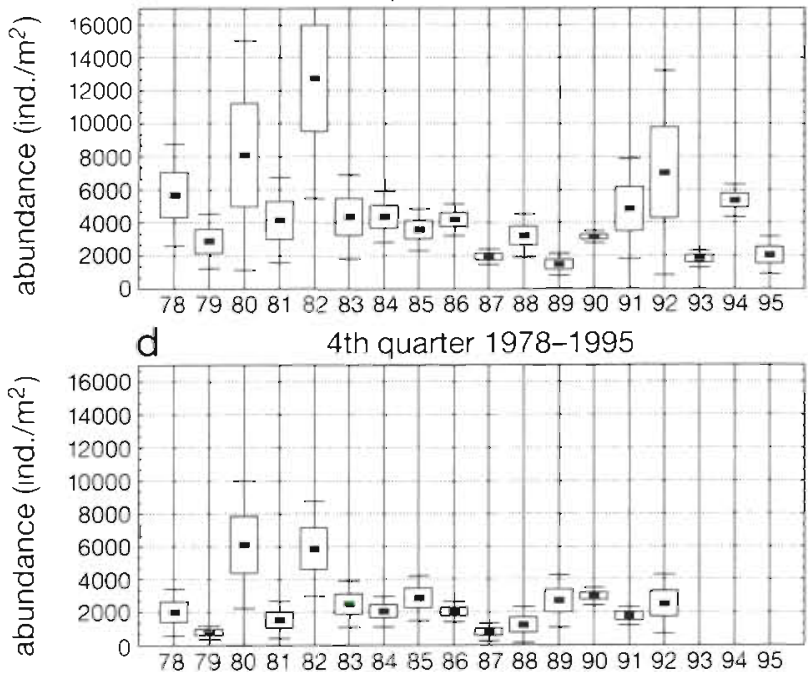

Fig 5 Mean abundance per $\mathrm{m}^{2}$ for the furst to fourth quarter (a to d) between 1978 and 1995 

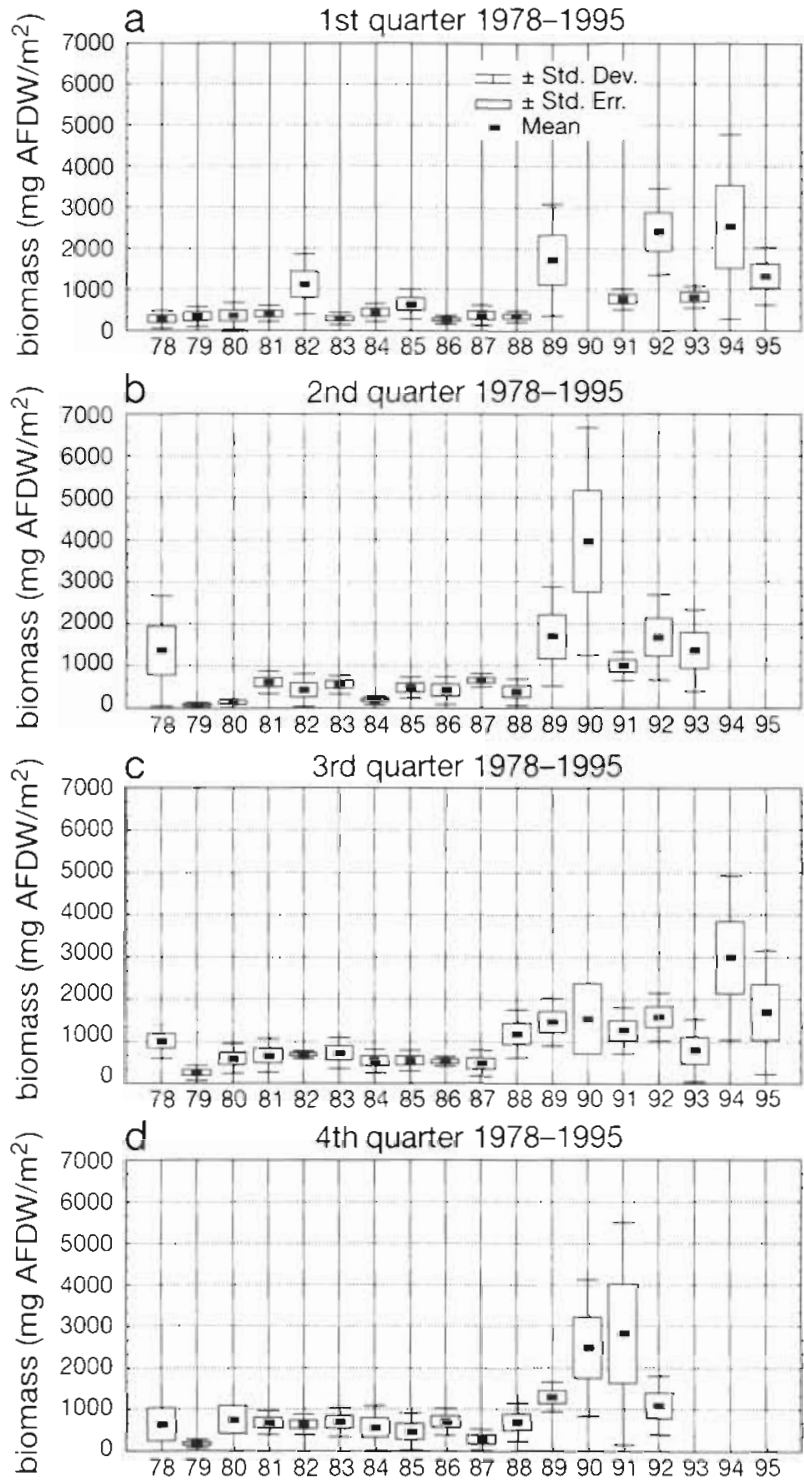

Fig. 6. Mean biomass per $\mathrm{m}^{2}$ for the first to fourth quarter (a to d) between 1978 and 1995 second quarter. This does not mean that no correlations exist at all between climate and benthos data in other quarters, instead it means that benthos data in the second quarter possess the highest correlations with climate. Secondly, climate data from winter and early spring are more strongly correlated to benthos than climate data from other seasons. Thirdly, the best climate predictors are SST, SLP and NAO index. Obtained skills for $\mathrm{T}$ and CYC were lower and no correlations at all were found between GSI, the mean sea level anomalies observed at the tide gauge of Helgoland, the runoff of the River Elbe, and benthos. Also, $\log$ abundance and species number were better predictands than log biomass.

Fig. 7 shows model 1 (for reference see Table 1). The 3 leading EOFs (which represent more than $90 \%$ of the 6-mo-averaged SLP variance) of December to May SLP are used to estimate the log abundance in the second quarter. The CCA pattern shows an anomalously high pressure in the north and an anomalously low pressure in the south, a combination that leads to anomalously weak westerly winds. This combination coincides with an anomaly in log abundance of -0.5 . In the same way, low pressure anomalies in the north and high pressure anomalies in the south coincide with positive anomalies in $\log$ abundance.

The depicted CCA pattern in Fig. 7 is practically identical to the first EOF of SLP and describes the NAO. It can be concluded that model 1 describes the same mechanism as model 2, which uses the NAOI as the predictor. The same can be shown for models 4 and 5 .

Model 3 is shown in Fig. 8. The leading 3 EOFs (which explain more than $95 \%$ of the 3-mo-averaged SST) of January to March SST in the southeastern North Sea are used to estimate the species number in the second quarter. The CCA pattern shows an anomalously warm southeastern North Sea, with the highest anomalies in the German Bight. This anomaly coincides with an anomalously high species number; in the

Table 1. The best of the detected combinations. All combinations possess a maximum of skill within a narrow range of time lags and clearly lower skills for any other time lags. In addition, the significance of the skill is $>99 \%$. A subscripted p to a predictor month indicates a month in the preceding vear. All combinations contained the benthos observations in the second quarter Anomalously high $\log$ abundances and species numbers in the second quarter seem to depend on anomalously mild 'westerly' climate conditions in winter or early spring. The left column contains reference model numbers that are used in the text

\begin{tabular}{|c|c|c|c|c|c|}
\hline \multirow[t]{2}{*}{ Model } & \multicolumn{3}{|c|}{ Combination } & \multicolumn{2}{|c|}{ Skill } \\
\hline & Predictor (months) & & Predictand (season) & $\mathrm{r}$ & $\beta$ \\
\hline 1 & SLP $\left(12_{p}-5\right)$ : westerly winds & and & high log-abundance (second) & 0.73 & 0.52 \\
\hline 2 & NAO index $\left(12_{p}-3\right)$ : westerly winds & and & high log abundance (second) & 0.73 & 0.52 \\
\hline 3 & SST $(1-3):$ warm North Sea & and & high species number (second) & 0.74 & 0.52 \\
\hline 4 & $\operatorname{SLP}\left(11_{p}-4\right)$ : westerly winds & and & high species number (second) & 0.66 & 0.38 \\
\hline 5 & NAO index $\left(12_{p}-3\right)$ : westerly winds & and & high species number (second) & 0.67 & 0.44 \\
\hline
\end{tabular}



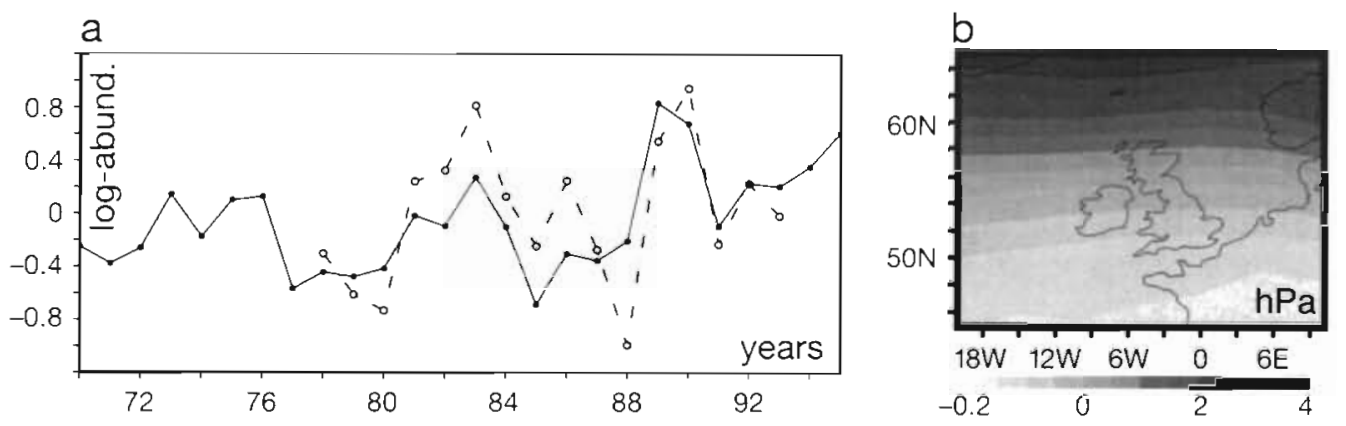

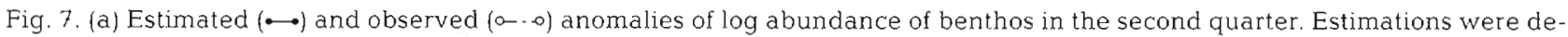
rived from the 3 leading EOFs of the December to May SLP. (b) The SLP CCA pattern describes a pressure anomaly of -1 hPa in the south and $+3 \mathrm{hPa}$ in the north and coincides with an anomaly in log abundance of -0.5 (the same is also true for the reverse situation, i.e. opposite signsj. Estimated and observed $\log$ abundance are correlated with $r=0.73$ and $\beta=0.52$

same way, an anomalously cold southeastern North Sea coincides with low species number.

The depicted SST anomaly is closely related to atmospheric circulation. The first SST EOF pattern (Fig. 2a) shows an anomalously warm (or cold) North Sea with the highest anomalies in the southeast. The tinite cuefficients of this pattern and the NAO index are correlated with $r=0.71$. Hence, SST and atmospheric circulation are closely related to each other in winter and it can be concluded that models 3,4 and 5 describe the same relationship. In addition, SST might be the mediating mechanism between SLP or NAO index and log abundance in models 1 and 2 .

Models 2 and 5 are shown in Fig. 9. Though these models possess 2 fewer degrees of freedom than models 1,3 and 4 (since they use a scalar predictor instead of 3 EOFs), they reach a similar skill. It has already been stated that the SLP CCA pattern from model 1 (Fig. 7) equals the first EOF of SLP and, hence, the NAO. A comparison between the first EOF of SST (Fig. 2) and the SST CCA pattern in Fig. 8 shows that these are similar as well. In both cases, the climate information that is important for the benthos is contained in the first EOF and the additional information in the second and third EOF does not improve the model any more. Hence, the simple model that uses the NAO index as predictor contains all the important information by itself and a multivariate regressinn is not necessary.

Finally, Fig. 9c shows the skill of a model that uses the NAO index to estimate the log biomass in the second quarter. A high NAO index coincides with a high biomass. The skill of the model is $r=0.56$ and $\beta=0.31$ and possesses a significance $>95 \%$ Hence, although the correlation is less clear than in models 1 to 5 , biomass seems to be related to the atmospheric circulation as well.

\section{DISCUSSION}

Since sediment composition and morphology did not change in the study area (Dörjes 1976, 1992, Dörjes et al. 1986. Hagendorff 1993) and hot summers or storm
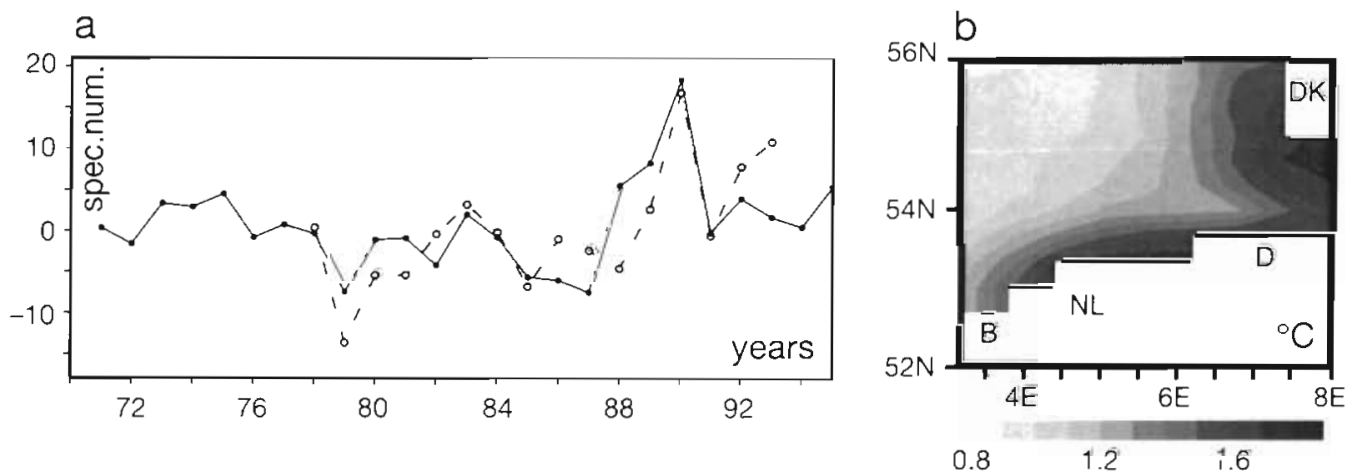

Fig. 8. (a) Estimated (•-) and observed (०- - ) anomalies of the species number of benthos in the second quarter. Estimations were derived from the 3 leading EOFs of the January to March SST. (b) The SST CCA pattern describes a SST anomaly of $+1.5^{\circ} \mathrm{C}$ in the German Bight and coincides with an anomaly in species number of +7.0 (the same is also true for the reverse situation). Estimated and observed species number are correlated with $r=0.74$ and $\beta=0.52$ 


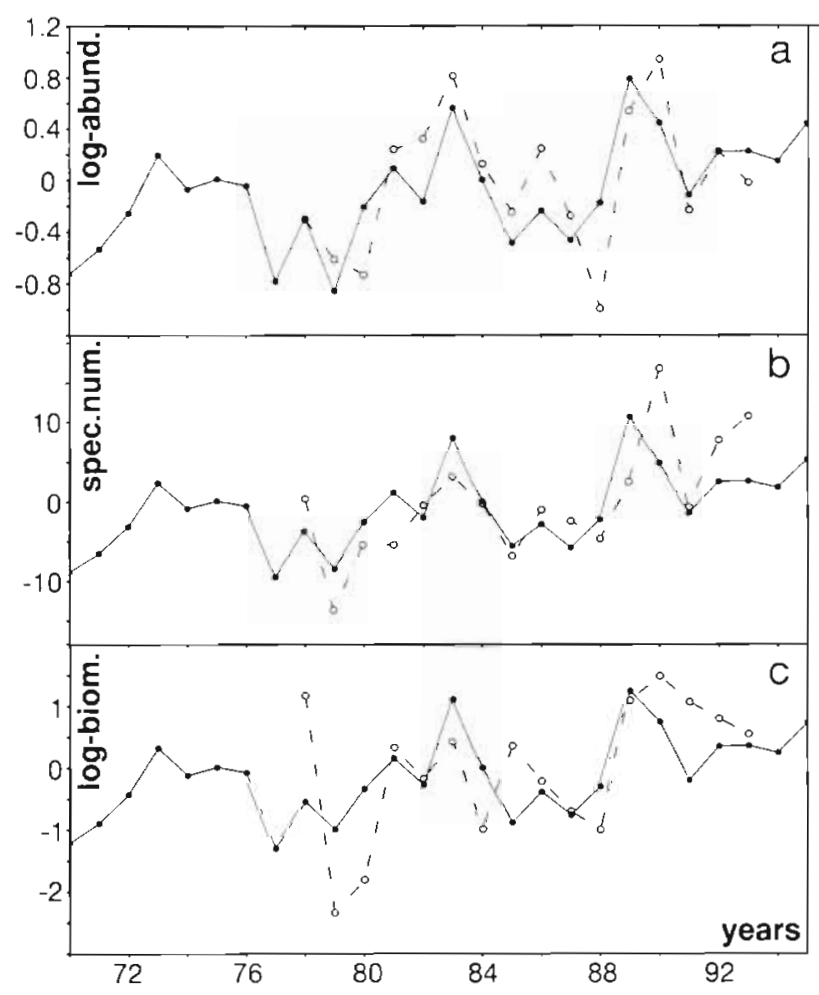

Fig. 9. Estimated $(\bullet)$ and observed $(0-\infty)$ anomalies of $(a) \log$ abundance, (b) species number and (c) log biomass of macrobenthos in the second quarter. The estimations were derived from the $\mathrm{NAO}$ index in the preceding winter. An anomalous NAO index of +1 is correlated with an anomalous $\log$ abundance of +0.3 , species number of $+3.8, \log$ biomass of +0.6 (the same is also true for the reverse situation). Estimations and observations are correlated with $\mathrm{r}=0.73, \beta=0.52$ (log abundance), $r=0.67, \beta=0.44$ (species number) and $r=0.56, \beta=0.31$ (log biomass)

events could not explain changes in the benthos, these factors can be excluded as possible causes for variability in the macrofauna. On the other hand, previous analyses of the Norderney benthic data using Multi Dimensional Scaling (MDS) and canonical correspondence analysis indicated that cold and mild winters are important determinants of changes in the macrofaunal communities (Kröncke et al. 1997, Zeiss \& Kröncke 1997). Furthermore, a possible synergistic effect of mild winters and observed eutrophication (Hanslik et al. 1994) was discussed by Kröncke et al. (1997).

Our study of benthic and large-scale climate data shows a clear relationship between climatic and biological parameters. Such a relationship was already described in the 'Introduction' for phytoplankton and pelagic fish stocks but relationships for benthic communities have been limited to small-scale studies of severe climatic events like cold winters and hot summers in combination with oxygen deficiency for spatially limited investigations (Ziegelmeier 1970, von
Westernhagen et al. 1986, Beukema 1992). On a larger scale Austen et al. (1991) and Buchanan (1993) found changes in benthic biomass at the Northumberland coast, UK, which correlated with the intensity of inflow of Atlantic water masses into the area of investigation.

In the present study, the strong correlations found between large-scale parameters, such as SLP (including NAO) and SST, and the benthos reflect the strong relationship between the climate in winter and spring and the species number and biomass of benthic communities in the second quarter of the subsequent year. Our analyses support the results of other studies that suggest that winter temperatures have a strong influence on the benthic communities. The sea urchin Echinocardium cordatum seems to be sensitive to low temperatures since it was almost absent in the German Bight after severe winters (Ziegelmeier 1964, Beukema 1985), but dominated the biomass of the macrofauna communities off Norderney in mild winters. In addition, during 1980 and 1986, 2 years which followed cold winters, the polychaetes Spiophanes bombyx and Scoloplos armiger occurred in large numbers. Ziegelmeyer (1970) correlated the dominance of sedentary sediment-feeding polychaetes like $S$. bombyx with the absence of the bivalve Fabulina fabula after cold winters. Beukema et al. (1988) also recorded low survival rates of $F$. fabula in the sublittoral Dutch Wadden Sea after the cold winter 1978/1979. On the other hand, during mild winters mortality, production and reproduction are not as reduced as in cold winters, while primary production starts earlier. The sum of all factors results in higher biomass, as documented in our data. In relation to eutrophication, the processes are similar to those described above for mild winters but the availability of food is higher, which might result in even stronger effects.

Since the best correlations between climatic and benthic parameters were found during the cold period of the year, this may indicate that the climatic factors at this time play a major role in structuring the benthos. Conversely, during the summer, biological processes like reproduction become stronger and may interact with, or obscure, the climatic factors. Beukema (1990, 1992), Reise (1993) and Beukema et al. (1996) confirmed the importance of cold winters for the structure of littoral benthic communities. Generally, highly successful recruitment after cold winters results in increased biomass (Beukema 1990, 1992). After warm. winters over a number of years, Beukema $(1990,1992)$ found increases in species number and stable total biomass, but a decrease in individual biomass of bivalves.

Therefore, single cold winters appear to have minor long-term effects on the benthic communities of sublittoral coastal regions in the North Sea. Periods of low temperature are part of the natural variability in the 
habitat and may even stabilize the system (Beukema 1990, 1992, Reise 1993). In contrast, mild winters winters over a number of years lead to distinct long-term changes in the subtidal benthic communities, as is seen in our data. These patterns contradict the one claimed for the Wadden Sea by Beukema $(1990,1992)$ and Reise (1993), but indicate a general difference in the functioning of benthic communities in eulittoral and sublittoral coastal areas.

For future observations our analyses suggest that changes in the NAO and in the SST might predict changes in the benthic system, e.g. a positive NAO index will result in an increase in benthic biomass of subtidal benthic communities.

Nevertheless, the changes cannot be foreseen since the analyses of time series data for other marine areas indicate the variety of biological responses to climate. An increase in temperature of 2 to $4^{\circ} \mathrm{C}$ might cause a shift in species composition similar to that observed on the Atlantic coast or during the Eem period of the last interglacial (van Straaten 1956, de Vooys 1990). We suggest that not only temperature but also the synergistic effects of changes in sainity and hydrodynamics together with human impacts like eutrophication will cause extreme future changes in the ecosystem. Such synergistic effects can only be estimated if we learn more about the relationship between climate and biology from recent data.

The general questions of whether and how community structure as well as biodiversity depends on the sensitivity of species to winter temperature can probably be answered by a correlation of climate parameters and abundance and biomass of single species. This future study will allow a better understanding of the functioning of the benthic ecosystem in relation to changes in the physical forcing

Acknowledgements. The authors are indebted to $\mathrm{Dr} \mathrm{G}$. Becker (BSH) for providing the North Sea SST data, to Dr J. Hurrell (NCAR) for the NAO data and to Dr M. Bergemann (ARGE) for the runoff data of the River Elbe. Parts of this paper were funded by the 'Umweltbundesamt' (project 20204270), the Commission of the European Community under DYNAMO (FAIR-CT95-0710) and the 'Deutsche Forschungsgemeinschaft' (STO 321/1-1). We thank Dr S. Jennings (CEFAS, Lowestoft) for correcting the English.

\section{LITERATURE CITED}

Aebischer NJ, Coulson JC, Colebrook JM (1990) Parallel long-term trends across four marine trophic levels and weather. Nature 347:753-755

Austen MC, Buchanan JB, Hunt HG, Josefson AB, Kendall. M. (1991) Comparison of long-term trends in benthic and pelagic communities of the North Sea. J Mar Biol Assoc UK 71:179-190

Barnston AG, Livezey RE (1987) Classifucation, seasonality and persistence of low-frequency atmospheric circulation patterns. Mon Weather Rev 115:1083-1126

Becker GA, Dick S, Dippner JW (1992) Hydrography of the German Bight. Mar Ecol Prog Ser 91(1/3):9-18

Becker GA, Dooley H (1995) The 1989/91 high salınity anomaly in the North Sea and adjacent areas. Ocean Challenge 6(1):52-57

Becker GA, Frey H, Wegner G (1986) Atlas der Temperatur an der Oberflache der Nordsee. Wochentliche und monatliche Mittelwerte für den Zeitraum 1971 bis 1980. Dtsch Hydrogr Z Ergebnis-Helfte B 17:1-127

Becker GA, Pauly M (1996) Sea surface temperature changes in the North Sea and their causes. ICES J Mar Sci 53: $887-898$

Beukema JJ (1979) Biomass and species richness of the macrobenthic animals living on a tidal flat area in the Dutch Wadden Sea: effects of a severe winter. Neth J Sea Res 13:203-223

Beukema JJ (1985) Growth and dymamics in populations of Echinocardium cordatum living in the North Sea off the Dutch North Coast. Neth J Sea Res 19(2):129-134

Beukema JJ (1990) Expected effects of changes in winter temperatures on benthic animals living in soft sediments in coastal North Sea areas. In: Beukema JJ, Wolff WJ, Brouns JWN (eds) Expected effects of climatic change on marine coastal ecosystems. Kluwer Academic Press, Dordrecht, p $83-92$

Beukema JJ (1991) Changes in composition of bottom fauna of a tidal-flat area during a period of eutrophication. Mar Biol 111:293-301

Beukema JJ (1992) Expected changes in the Wadden Sea benthos in a warmer world: lessons from periods with mild winters. Neth J Sea Res 30:73-79

Beukema JJ, Cadée GC (1986) Zoobenthos responses to eutrophication of the Dutch Wadden Sea. Ophelia 26: $55-64$

Beukema JJ, Dörjes J, Essink K (1988) Latitudinal differences in survival during a severe winter in macrozoobenthic species sensitive to low temperatures. Senckenb Marit 20: $19-30$

Beukema JJ, Essink K, Michaelis $H$ (1996) The geographic scale of synchronized fluctuation patterns in zoobenthic populations as a key to underlying factors: climatic or man-induced. ICES J Mar Sci 53:964-971

Binet D (1997) Climate and pelagic fisheries in the Canary and Guinea currents 1964-1993: the role of trade winds and the southern oscillation. Oceanol Acta 20(1):177-190

Blackmon ML (1976) A climatological spectral study of the 500 mbar geopotential height of the northern hemisphere. J Atmos Sci 33:1607-1623

Borchardt T, Burchert S, Hablizel H, Karbe L, Zeitner R (1988) Trace metal concentrations in mussels: comparison between estuarine, coastal and offshore regions in the southeastern North Sea from 1983 to 1986. Mar Ecol Prog Ser 42:17-31

Buchanan JB (1993) Evidence of benthic pelagic coupling at a station off the Northumberland coast. J Exp Mar Biol Ecol $172: 1-10$

Cadée GC, Hegemann J (1991) Phytoplankton composition, primary production, and chlorophyll: organic carbon and turbidity in the Marsdiep in 1990 compared with earlier years. Hydrobiol Bull 25:29-35

Colebrook JM (1986) Environmental influences on long-term variability in marine plankton. Hydrobiologica 142:309-325

Colebrook JM, Taylor AH (1984) Significant time scales of long-term variability in the plankton and environment. Rapp P-V Reun Cons Int Explor Mer 183:20-26

Cushing DH (1978) Biological effects of climatic change. Rapp 
P-V Reun Cons Int Explor Mer 173:107-116

Cushing DH, Dickson RR (1976) The biological response in the sea to climatic changes. Adv Mar Biol 14:2-122.

Daan N, Bromley PJ, Hislop JRG, Nielsen NA (1990) Ecology of North Sea fish. Neth J Sea Res 26(2/4):343-386

de Groot SJ, Lindeboom HJ (1994) Environmental impact of bottom gears on benthic fauna in relation to natural resources management and protection of the North Sea. NIOZ Rapp 1994 11:1-225

Deutsches Hydrographisches Institut (1984) Deutsche Bucht, Hydrographie. Meereskundliche Beobachtungen und Ergebnisse Nr 57

de Vooys CGN (1990) Expected biological effects of longterm changes in temperatures on benthic ecosystems in coastal waters around the Netherlands. In: Beukema JJ, Wolff WJ, Brouns JWM (eds) Expected effects of climate change on marine coastal ecosystems. Kluwer Academic Press, Dordrecht, $p$ 77-82

Dickson RR, Meincke J, Malberg SA, Lee AJ (1988) The 'great salinity anomaly' in the northern North Atlantic 1968-1982. Prog Oceanogr 20:103-151

Dippner JW (1998a) A note on SST anomalies in the North Sea in relation to the North Atlantic Oscillation and the potential influence on the theoretical spawning time of fish. Dtsch Hydrogr Z (in press)

Dippner JW (1998b) Recruitment success of different fish stocks in the North Sea in relation to climate variability. Dtsch Hydrogr Z (in press)

Dörjes J (1976) Primärgefüge, Bioturbation und Makrofauna als Indikatoren des Sandversatzes im Seegebiet vor Norderney (Nordsee). II. Zonierung und Verteilung der Makrofauna. Senckenb Marit 8:171-188

Dörjes J (1992) Langfristige Veränderungen des Artenbestandes der Makroendofauna im Vorstrand der Düneninsel Norderney in der Zeit von 1976 bis 1988 (Nordsee). Senckenb Marit 22:11-19

Dörjes J, Michaelis H, Rohde B (1986) Long-term studies of macrozoobenthos in the intertidal and shallow subtidal habitats near the island of Norderney (East Frisian coast, Germany). Hydrobiologia 142:217-232

Hagendorff R (1993) Untersuchungen zur räumlichen und zeitlichen Variabilität des Makrozoobenthos im Vorstrandbereich von Norderney in den Jahren 1990 und 1991. Diploma thesis, University of Oldenburg

Hanslik M, Rahmel J, Bätje M, Knieriemen S, Schneider G, Dick S (1994) Der Jahresgang blütenbildender und toxischer Algen an der niedersächsischen Küste seit 1982. Umweltbundesamt Berlin Final Rep 95-056:1-210

Heyen H, Dippner JW (1996) Salinity in the southern German Bight estimated from large-scale climate data. Externer GKSS-Report 96/E/91, Geesthacht

Heyen H, Dippner JW (1998) Salinity variability in the German Bight in relation to climate variability. Tellus (in press\}

Heyen $H$, Zorita E, von Storch H (1996) Statistical downscaling of monthly mean North Atlantic air-pressure to sea level anomalies in the Baltic Sea. Tellus A 48:312-323

Hickel W, Mangelsdorf P, Berg J (1993) The human impact in the German Bight: eutrophication during three decades (1962-1991). Helgoländer Wiss Meeresunters 47:243-263

Hurrell JW (1995) Decadal trends in the North Atlantic Oscillation: regional temperatures and precipitation. Science 269:676-679

Jones PD (1994) Hemispheric surface air temperature variations: a reanalysis and an update to 1993. J Clim 7: $1794-1802$

Karbe L, Gonzalez-Valero J, Borchardt T, Dembinski M,
Duch A, Hablizel H, Zeitner R (1988) Heavy metals in fish and benthic organisms from the northwestern, central and southern North Sea: regional patterns comparing dab, blue mussel and hermit crab. ICES CM E:22:1-14

Kersten M, Kröncke I (1991) Bioavailability of lead in North Sea sediments. Helgoländer Wiss Meeresunters 45:403-409 Kröncke I (1992) Macrofauna standing stock of the Dogger Bank. A comparison: III. 1950-54 versus 1985-87 A final summary. Helgoländer Wiss Meeresunters 46:137-169

Kröncke I (1995) Long-term changes in North Sea benthos. Senckenb Marit 26(1/2):73-80

Kröncke I, Zeiss B, Dahms S (1997) Makrofauna-Langzeitreihe im Inselvorfeld von Norderney. Umweltbundesamt Berlin Final Rep 98-021:1-139

Kushnir Y, Wallace JM (1989) Low-frequency vanability in the northern hemisphere winter: geographical distribution, structure and time-scale dependence. J Atmos Sci 46 : $3122-3142$

Laevastu T (1962) Water types in the North Sea and their characteristics. Hawaii Inst Geophys Honolulu Rep No. 24

Lamb PJ, Peppler RA (1987) North Atlantic Oscillation: concept and an application. Bull Am Meteorol Soc 68 : $1218-1225$

Lindeboom $\mathrm{H}$, van Raaphorst W, Beukema J, Cadée $\mathrm{G}$, Swennen C (1995) (Sudden) Changes in the North Sea and Wadden Sea: oceanic influences underestimated? Dtsch Hydrogr Z Suppl 2:87-100

Livezey RE (1995) The evaluation of forecasts. In: von Storch H, Navarra A (eds) Analysis of climate variability: applications of statistical techniques. Springer-Verlag, Berlin, p $177-195$

Maak K, von Storch H (1997) Statistical downscaling of monthly mean air-temperature to the beginning of the flowering of Galanthus nivalis L. in Northern Germany. Int $\mathrm{J}$ Biometeorol 41:5-12

Mantua NJ, Hare SR, Zhang $\mathrm{X}$, Wallace JM, Francix RC (1997) A Pacific interdecadal climate oscillation with impacts on salmon production. Bull Am Meteorol Soc 78: $1069-1079$

Michaelsen J (1987) Cross-validation in statistical climate forecast models. J Clim Appl Meteorol 26:1589-1600

Mittelstaedt E (1969) Synoptische Ozeanographie in der Nordsee. Ber Dtsch Wiss Komm Meeresforsch 20:87-100

Nehring S (1994) Gymnodinium catenatum Graham (Dinophyceae) in Europe: a growing problem? J Plankton Res 17:85-102

Rachor E (1990) Changes in sublittoral zoobenthos in the German Bight with regard to eutrophication. Neth J Sea Res 25(1/2):209-214

Rachor E, Gerlach SA (1978) Changes of macrobenthos in a sublittoral sand area of the German Bight, 1967-1975. Rapp P-V Reun Cons lnt Explor Mer 172:418-431

Rees HL, Eleftheriou A (1989) North Sea benthos: a review of field investigations into biological effects of man's activities. J Cons Int Explor Mer 45:284-305

Reise K (1993) Die verschwommene Zukunft der Nordseewatten. In: Schellnhuber HJ Sterr H (eds) Klimaänderung und Küste. Springer-Verlag, Berlin, p 223-232

Rosenberg R, Gray JS, Josefson AB, Pearson TH (1987) Petersen's benthic stations revisited. Il. Is the Oslofjord and eastern Skagerrak enriched? J Exp Mar Biol Ecol 105 $219-251$

Russell FS (1973) A summary of the observations on the occurrence of planktonic stages of fish off Plymouth 1924-1952. J Mar Biol Assoc UK 53:347-356

Steele JH (1974) The structure of marine ecosystems. Harvard University Press, Cambridge, MA 
Swennen C (1991) Fledging production of Eiders Somateria mollisina in The Netherlands. J Ornithol 132:427-437

Taylor AH (1995) North-south shifts of the Gulf Stream and their climatic connection with the abundance of zooplankton in the UK and its surrounding seas. ICES J Mar Sci 52:711-721

Trenberth KE, Paolino DA Jr (1980) The northern hemisphere SLP-dataset: trends, errors and discontinuities. Mon Weather Rev 112:1999-2015

van Straaten IMJU (1956) Composition of shell beds formed in tidal flat environments in The Netherlands and in the Bay of Arcachon (France). Geol Mijnbouw 18:206-226

von Storch H (1995) Spatial patterns: EOFs and CCA. In: von Storch $H$, Navarra A (eds) Analysis of climate variability: applications of statistical techniques. Springer-Verlag, Berlin, p 227-257

von Storch H, Zorita E, Cubasch U (1993) Downscaling of global climate change estimates to regional scales: an

Editorial responsibility: Otto Kinne (Editor),

Oldendorf/Luhe, Germany application to Iberian rainfall in wintertime. J Clim 6: $1161-1171$

von Westernhagen $\mathrm{H}$, Hickel W, Bauerfeind $E$, Niermann U, Kröncke I (1986) Sources and effects of oxygen deficiencies in the southeastern North Sea. Ophelia 26:457-473

Walker GT, Bliss EW (1932) World weather V. Mem R Soc 4: $53-84$

Zeıss B, Kröncke I (1997) Macrofauna long-term studies in a subtidal habitat off Norderney (East Frisia, Germany) from 1978 to 1994. I. The late winter samples. Oceanol Acta 20(1):311-318

Ziegelmeier E (1964) Einwirkungen des kalten Winters 1962/63 auf das Makrobenthos im Ostteil der Deutschen Bucht. Helgoländer Wiss Meeresunters 10:276-282

Ziegelmeier E (1970) Über Massenvorkommen verschiedener makrobenthaler Wirbelloser während der Wiederbesiedlungsphase nach Schädigungen durch 'katastrophale' Umwelteinflüsse. Helgoländer Wiss Meeresunters 21:9-20

Submitted: November 10, 1997; Accepted: March 23, 1998

Proofs received from author(s): May 28, 1998 